Article

\title{
Chenopodium album L. and Sisymbrium officinale (L.) Scop.: Phytochemical Content and In Vitro Antioxidant and Anti-Inflammatory Potential
}

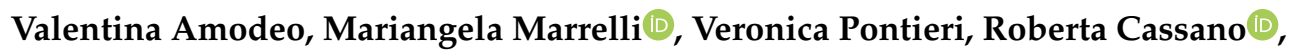 \\ Sonia Trombino, Filomena Conforti $(\mathbb{D})$ and Giancarlo Statti * \\ Department of Pharmacy, Health and Nutritional Sciences, University of Calabria, 87036 Rende (CS), Italy; \\ valentina.amodeo@unical.it (V.A.); mariangela.marrelli@unical.it (M.M.); veronicapontieri@libero.it (V.P.); \\ roberta.cassano@unical.it (R.C.); sonia.trombino@unical.it (S.T.); filomena.conforti@unical.it (F.C.) \\ * Correspondence: giancarlo.statti@unical.it; Tel.: +39-0984-493063; Fax: +39-0984-493107
}

Received: 17 October 2019; Accepted: 13 November 2019; Published: 15 November 2019

\begin{abstract}
Spontaneous edible plants have an old history of use in popular traditions all around the world, and the rediscovery of these species could also be useful for the search of new drugs. Chenopodium album L. (Amaranthaceae) and Sisymbrium officinale (L.) Scop. (Brassicaceae) are two annual plants traditionally used both as food and herbal remedies against inflammatory disorders. In this work, the potential anti-inflammatory and anti-arthritic activities of these plant species have been investigated, together with their antioxidant potential. The phytochemical composition was assessed as well by means of gas chromatography coupled to mass spectrometry (GC-MS) and high performance thin layer chromatography (HPTLC). The antioxidant properties were assessed using the DPPH and $\beta$-carotene bleaching test. The ability of extracts to protect against lipid peroxidation was also examined in rat-liver microsomal membranes. All the samples showed a preservation of antioxidant activity up to $60 \mathrm{~min}$. A significant inhibitory activity on the production of the pro-inflammatory mediator nitric oxide was induced in lipopolysaccharide (LPS)-stimulated RAW 264.7 cells by the dichloromethane fraction of $C$. album extract, with an $\mathrm{IC}_{50}$ value equal to $81.7 \pm 0.9 \mu \mathrm{g} / \mathrm{mL}$. The same sample showed also a concentration-dependent anti-denaturation effect on heat-treated bovine serum albumin $\left(\mathrm{IC}_{50}=975.6 \pm 5.5 \mu \mathrm{g} / \mathrm{mL}\right.$ ), even if the best in vitro anti-arthritic activity was observed for the dichloromethane fraction of $S$. officinale extract, with an $\mathrm{IC}_{50}$ value of $680.9 \pm 13.2 \mu \mathrm{g} / \mathrm{mL}$.
\end{abstract}

Keywords: anti-arthritic; anti-denaturation property; antioxidant; bovine serum albumin; Chenopodium; nitric oxide; Sisymbrium

\section{Introduction}

Chenopodium album L. (Amaranthaceae), commonly known as pigweed, is an annual herb growing widely in open habitats such as roadsides and riverbanks [1]. This plant was used in folk medicine as antihelmintic, laxative, as a blood purifier, and it was also used for the treatment of hepatic disorders, intestinal ulcers, and burns [2]. Beside these traditional uses, this species is a known antirheumatic remedy in the traditional medicine of Lebanon. The decoction of its aerial parts mixed with alcohol was utilized against rheumatism and arthritis [3]. C. album is common in Italy, where it is also known as fat hen, and traditionally consumed boiled or used in salads, soups, and stews [4].

Sisymbrium officinale (L.) Scop. (synonym Erysimum officinale L., Brassicaceae) is an annual plant present in Europe, Asia, and northern Africa. It is commonly called hedge mustard, but is also known as "singer's plant", because of its traditional use in vocal tract diseases: Flowers and leaves 
were used for preparing decoctions or tinctures for the treatment of sore throats, coughs, hoarseness, laryngitis, and pharyngitis [5,6]. S. officinale is rich in sulfated compounds (particularly glucosinolates, isothiocyanates and sulfated lactones), to which its beneficial properties have been related. However, despite its traditional use, this plant has not yet been deeply investigated [7]. Moreover, shoots and leaves of the wild plant have been traditionally used also as food, in salads $[8,9]$.

Wild edible plants have always been important in the popular traditions of many Mediterranean countries, and ethno-directed research is very useful in the discovery of new drug and food resources [10]. Ethnobotany is a discipline that focuses on the relationships between humans and plants, and it is based on the use of methods from both social and natural sciences. Bioprospecting for new drugs of plant origin, a more powerful tool than random assays for the finding of new active compounds, has classically been based on ethnobotanical information [11,12].

The anti-rheumatic potential of C. album was already investigated by Arora and coworkers, who tested the acetone extract of aerial parts on Complete Freund's adjuvant induced rheumatoid arthritis in rats. The authors reported that the extract was able to induce a significant reduction in rat paw edema (80.13\%) after 21 days of treatment at the dose of $200 \mathrm{mg} / \mathrm{kg}$ per os, and they also proved that the antirheumatic activity was linked to the inhibition of NF kappa B (NFkB) protein [13].

Politi and colleagues tested the anti-inflammatory activity of $S$. officinale dichloromethane and methanol extracts in the murine Croton oil-induced ear edema model, but just a modest effect was observed at the highest concentrations [14].

Here, in our efforts to investigate the potential health benefits of wild edible plants from Southern Italy [15-18], we wanted to deeply investigate C. album and S. officinale biological properties. Together with the antioxidant activity, the potential anti-inflammatory and anti-arthritic activities of these plant species have been investigated. Methanolic extracts and their fractions were tested for their ability to inhibit the lipopolysaccharide (LPS)-induced production of nitric oxide (NO) in the murine macrophage RAW 264.7 cell line, and their capacity to protect bovine serum albumin from heat denaturation. The phytochemical profile has been elucidated as well by means of gas chromatography-mass spectrometry (GC-MS) and high performance thin layer chromatography (HPTLC).

To the best of our knowledge, this is the first report concerning the in vitro anti-denaturation effects on bovine serum albumin for these species.

\section{Results and Discussion}

\subsection{Phytochemical Profile}

The aerial parts of wild C. album and S. officinale from Southern Calabria (Italy) were extracted with methanol through maceration. Obtained yields were $23.2 \%$ and $10.6 \%$ for the two raw extracts, respectively (Table 1). A fraction of each crude extract was then successively extracted with solvents with different polarity, $n$-hexane (yield $0.9 \%$ for both plant species, referred to dry plant material), dichloromethane (1.6\% and 2.2, for C. album and S. officinale, respectively), and ethyl acetate $(0.3 \%)$. Remaining aqueous fractions $(20.4 \%$ and $7.2 \%)$ were investigated as well.

Table 1. Investigated plants: Extraction yields and total phenolic and flavonoid contents.

\begin{tabular}{cccccc}
\hline Botanical Name & Family & $\begin{array}{c}\text { Voucher } \\
\text { Number }\end{array}$ & Yield (\%) & TP $^{\mathbf{1}}$ & TF $^{\mathbf{2}}$ \\
\hline Chenopodium album L. & Amaranthaceae & 26247 & 23.2 & $12.8 \pm 1.6$ & $0.77 \pm 0.01$ \\
Sisymbrium officinale (L.) Scop. & Brassicaceae & 26236 & 10.6 & $8.1 \pm 0.1$ & $0.50 \pm 0.01$ \\
\hline
\end{tabular}

${ }^{1}$ Total phenolic content. ${ }^{2}$ Total flavonoid content. Data are expressed as mean \pm SE $(n=3)$. Results were expressed as $\mathrm{mg}$ of chlorogenic acid or quercetin equivalent per $\mathrm{g}$ of dry plant material, respectively.

The phytochemical content of the apolar fractions was assessed by means of GC-MS. The $n$-hexane samples were particularly rich in fatty acids, being palmitic acid the most abundant one $(15.7 \%$ and $10.0 \%$ of total peak areas in total ion current (TIC) for C. album and S. officinale, respectively, Table 2). 
Table 2. Phytochemical profile of $n$-hexane fractions of Chenopodium album L. and Sisymbrium officinale (L.) Scop.

\begin{tabular}{|c|c|c|c|}
\hline \multirow{2}{*}{ Compound $^{1}$} & \multirow{2}{*}{$\mathrm{Rt}^{2}$} & \multicolumn{2}{|l|}{$\mathbf{R A P}^{3}$} \\
\hline & & C. album $\mathrm{L}$. & S. officinale (L.) Scop. \\
\hline \multicolumn{4}{|l|}{ Fatty Acids } \\
\hline Caprylic acid & 10.106 & $\operatorname{Tr}^{4}$ & $\operatorname{Tr}$ \\
\hline Pelargonic acid & 12.00 & - & 0.1 \\
\hline Lauric acid & 15.044 & $\operatorname{Tr}$ & 0.1 \\
\hline Myristic acid & 16.799 & 0.7 & 0.3 \\
\hline 4,8,12-Trimethyltridecanoic acid & 16.930 & - & 0.1 \\
\hline Pentadecanoic acid & 17.616 & $\operatorname{Tr}$ & 0.2 \\
\hline $\begin{array}{l}\text { Tetradecanoic acid, } \\
\text { 5,9,13-trimethyl- }\end{array}$ & 17.708 & $\operatorname{Tr}$ & - \\
\hline Palmitelaidic acid & 18.096 & $\operatorname{Tr}$ & - \\
\hline Palmitic acid & 18.159 & 15.7 & 10.0 \\
\hline Oleic acid & 18.531 & $\operatorname{Tr}$ & - \\
\hline Margaric acid & 18.902 & 0.3 & - \\
\hline Isooleic acid & 19.456 & 0.8 & - \\
\hline Stearic acid & 19.634 & 1.3 & 1.0 \\
\hline Arachidic acid & 20.988 & 0.8 & 1.0 \\
\hline Linoleic acid & 21.051 & - & 0.5 \\
\hline Behenic acid & 22.274 & 0.9 & 0.8 \\
\hline Tricosylic acid & 22.966 & $\operatorname{Tr}$ & 0.4 \\
\hline Lignoceric acid & 23.731 & - & 0.6 \\
\hline Pentacosylic acid & 24.696 & - & 0.3 \\
\hline Cerotic acid & 25.829 & - & 0.9 \\
\hline Montanic acid & 28.847 & - & $\operatorname{tr}$ \\
\hline \multicolumn{4}{|l|}{ Terpenes } \\
\hline Dihydroactinidiolide & 14.987 & 0.9 & 0.4 \\
\hline Neophytadiene & 17.473 & 0.7 & - \\
\hline \multicolumn{4}{|l|}{ Phytosterols } \\
\hline$\beta$-Sitosterol & 33.882 & 3.2 & - \\
\hline
\end{tabular}

${ }^{1}$ Compounds listed in order of elution from SE30 MS column. ${ }^{2}$ Retention time (as min). ${ }^{3}$ Relative area percentage (peak area relative to total peak area in total ion current (TIC) \%). ${ }^{4} \mathrm{Tr}$ : Traces percentages $<0.1 \%$.

Stearic acid $(1.3 \%$ and $1.0 \%)$ and arachidic acid $(0.8 \%$ and $1.0 \%)$ were detected to a lesser extent. The other fatty acids were only found at percentages $<1.0 \%$. Two terpenes were also identified in C. album $n$-hexane fraction: The diterpene neophytadiene $(0.7 \%)$ and the monoterpene dihydroactinidiolide $(0.9 \%)$ also identified in S. officinale sample $(0.4 \%)$. Moreover, the presence of $\beta$-sitosterol was also recognized in C. album.

Table 3 reports the chemical composition of the two dichloromethane fractions. The monoterpene lactone loliolide was the most abundant compound in C. album (1.7\%), followed by methylethylmaleimide (1.4\%). This last compound was also identified in S. officinale, even if at a lesser extent $(0.3 \%)$. The phenylpropanoid coniferyl alcohol $(1.2 \%)$ and the hydroxycinnamic acid ferulic acid $(0.7 \%)$ were instead the most abundant compounds in S. officinale. 
Table 3. Chemical composition of dichloromethane fractions of Chenopodium album L. and Sisymbrium officinale (L.) Scop. methanolic extracts.

\begin{tabular}{cccc}
\hline Compound $^{\mathbf{1}}$ & \multirow{2}{*}{$\mathbf{R t}^{\mathbf{2}}$} & \multicolumn{2}{c}{ RAP $^{3}$} \\
\cline { 3 - 4 } & & C. album $\mathbf{L}$. & S. officinale (L.) Scop. \\
\hline Phenol & 7.677 & - & $\operatorname{Tr}^{4}$ \\
Benzoic acid & 10.758 & 1.0 & - \\
Methylethylmaleimide & 11.575 & 1.4 & 0.3 \\
2,4-Di-tert-butylphenol & 14.621 & - & $\mathrm{Tr}$ \\
Loliolide & 17.073 & 1.7 & - \\
Coniferyl alcohol & 17.250 & - & 1.2 \\
Ferulic acid & 17.565 & - & 0.7 \\
\hline
\end{tabular}

${ }^{1}$ Compounds listed in order of elution from SE30 MS column. ${ }^{2}$ Retention time (as min). ${ }^{3}$ Relative area percentage (peak area relative to total TIC peak area \%). ${ }^{4}$ Tr: Traces percentages $<0.1 \%$.

Total phenolic and total flavonoid contents of C. album and S. officinale raw extracts were also assessed. The amounts were expressed as chlorogenic acid and quercetin equivalents per $\mathrm{g}$ of dry material, respectively. C. album showed the highest amounts, with $12.8 \pm 1.6 \mathrm{mg} / \mathrm{g}$ of phenolic compounds and $0.77 \pm 0.01 \mathrm{mg} / \mathrm{g}$ of flavonoids, while values of $8.1 \pm 0.1$ and $0.50 \pm 0.01$ were observed for S. officinale (Table 1), respectively. With the aim to identify the most interesting phenolic compounds, the polar fractions of both plant extracts were then investigated by means of HPTLC, chosen as a practical solution to characterize the complex mixtures of substances present in natural products [19]. Analyses allowed to tentatively identify the presence of rutin and chlorogenic acid (Figure 1).

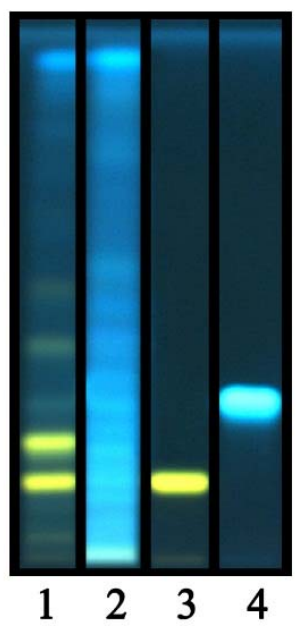

A

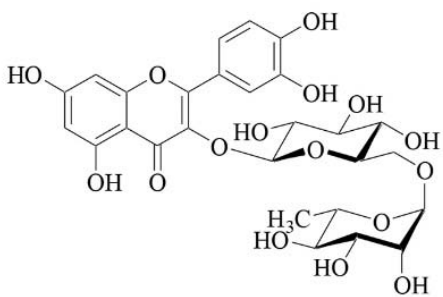

$\mathrm{B}$

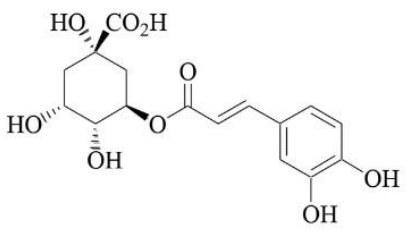

$\mathrm{C}$

Figure 1. (A) High performance thin-layer chromatography (HPTLC) analysis of the ethyl acetate fractions of investigated plants. Mobile phase: Ethyl acetate/dichloromethane/acetic acid/formic acid/water (100:25:10:10:11, v/v/v/v/v). Visualization-366 nm, derivatization-Natural Product Reagent (NPR). Tracks: 1, C. album L.; 2, S. officinale (L.) Scop.; 3, rutin; 4, chlorogenic acid. (B) Rutin.

(C) Chlorogenic acid.

The flavonoid glycoside rutin was detected in the EtOAc fraction of C. album, as indicated by the typical yellow spot after post chromatographic exposure to NP reagent. Chlorogenic acid was instead identified in the ethyl acetate fractions of both plant species, and it is recognizable as a blue spot in Figure 1. Figure 2 reports the chromatographic profiles of investigated samples and reference standards. 

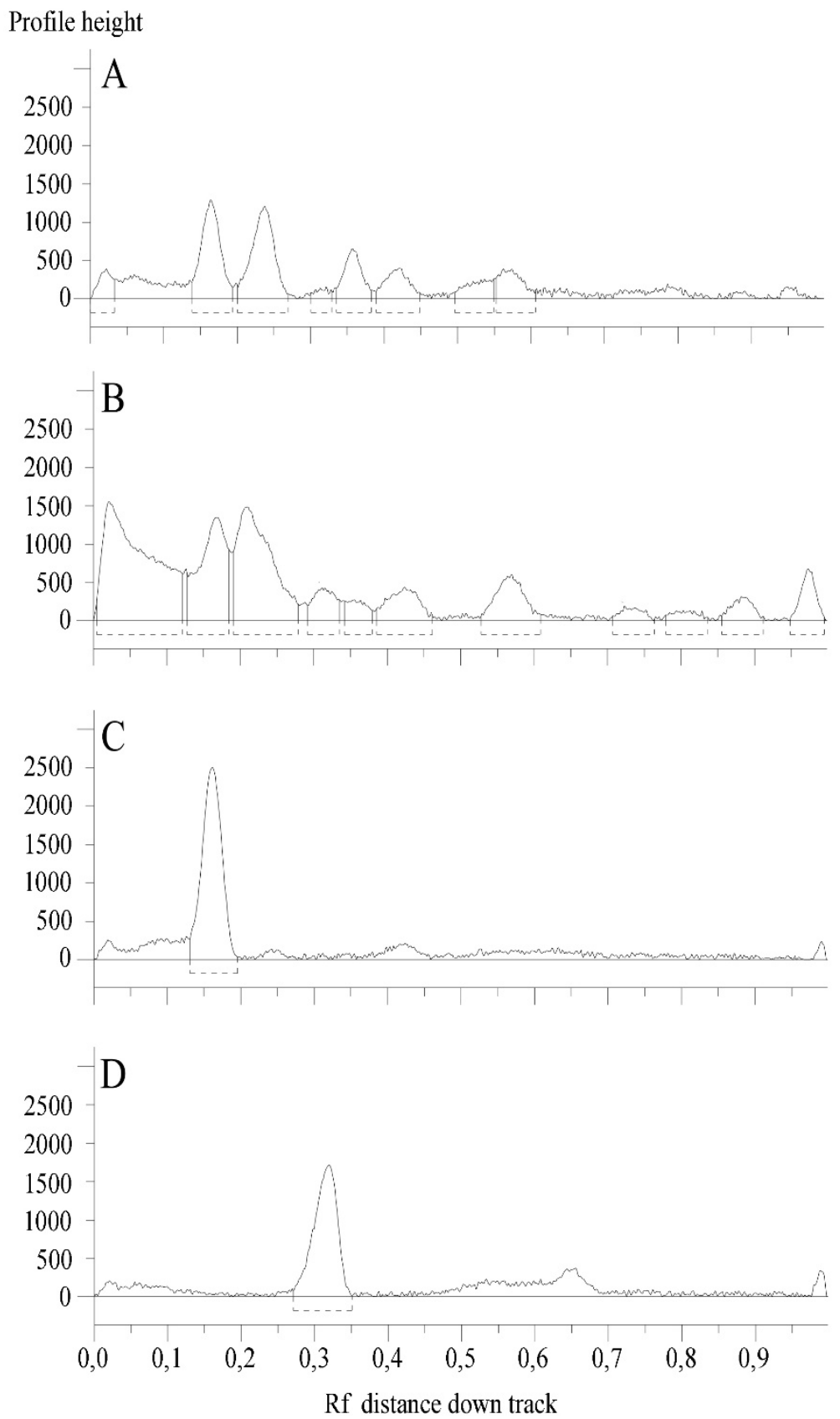

Figure 2. HPTLC chromatograms of analyzed samples and standards. (A) C. album L.; (B) S. officinale (L.) Scop.; $(\mathbf{C})$ rutin $(\mathrm{Rf}=0.16)$; $(\mathrm{D})$ chlorogenic acid $(\mathrm{Rf}=0.32)$.

\subsection{Antioxidant Activity}

The in vitro antioxidant capacities of $C$. album and $S$. officinale extracts and fractions were first evaluated by means of the DPPH and $\beta$-carotene bleaching methods. Almost all the samples demonstrated radical scavenging potency. The relation between concentration and percentage inhibition was explained by non-linear regression models. A strong association between concentration and percentage inhibition was observed. As regards the two raw extracts, S. officinale $\left(\mathrm{IC}_{50}=143.00 \pm 2.61 \mu \mathrm{g} / \mathrm{mL}\right.$, Table 4$)$ exerted a better radical scavenging potency than C. album $\left(\mathrm{IC}_{50}=\right.$ $172.70 \pm 2.18 \mu \mathrm{g} / \mathrm{mL}, P<0.05$, Bonferroni post-hoc test). The best activity was demonstrated by the ethyl acetate fraction of $S$. officinale, with an $\mathrm{IC}_{50}$ value of $60.11 \pm 1.79 \mu \mathrm{g} / \mathrm{mL}$. 
Table 4. In vitro antioxidant activity of plants extract and fractions.

\begin{tabular}{|c|c|c|c|c|}
\hline \multirow[t]{3}{*}{ Species } & \multirow[t]{3}{*}{ Sample } & \multicolumn{3}{|c|}{$\mathrm{IC}_{50}(\mu \mathrm{g} / \mathrm{mL})$} \\
\hline & & \multirow[t]{2}{*}{ DPPH Test } & \multicolumn{2}{|c|}{$\beta$-carotene Bleaching Test } \\
\hline & & & $30 \mathrm{~min}$ & $60 \mathrm{~min}$ \\
\hline C. album $\mathrm{L}$. & $\begin{array}{c}\text { Raw extract } \\
n \text {-Hexane } \\
\mathrm{CH}_{2} \mathrm{Cl}_{2} \\
\text { EtOAc } \\
\mathrm{H}_{2} \mathrm{O}\end{array}$ & $\begin{array}{c}172.70 \pm 2.18^{\mathrm{d}} \\
>1000 \\
435.60 \pm 12.97^{\mathrm{f}} \\
140.40 \pm 4.36^{\mathrm{c}} \\
>1000\end{array}$ & $\begin{array}{c}60.51 \pm 2.34^{\mathrm{e}} \\
>100 \\
>100 \\
12.07 \pm 0.04^{\mathrm{b}} \\
>100\end{array}$ & $\begin{array}{c}>100 \\
>100 \\
>100 \\
38.03 \pm 1.88^{\mathrm{d}} \\
>100\end{array}$ \\
\hline S. officinale (L.) Scop. & $\begin{array}{c}\text { Raw extract } \\
n \text {-Hexane } \\
\mathrm{CH}_{2} \mathrm{Cl}_{2} \\
\text { EtOAc } \\
\mathrm{H}_{2} \mathrm{O}\end{array}$ & $\begin{array}{c}143.00 \pm 2.61^{\mathrm{c}} \\
>1000 \\
>1000 \\
60.11 \pm 1.79^{\mathrm{b}} \\
262.9 \pm 0.93^{\mathrm{e}}\end{array}$ & $\begin{array}{c}2.61 \pm 0.06^{\mathrm{a}, \mathrm{b}} \\
>100 \\
61.02 \pm 2.31^{\mathrm{e}} \\
12.62 \pm 0.75^{\mathrm{b}} \\
>100\end{array}$ & $\begin{array}{c}8.53 \pm 0.27^{b} \\
>100 \\
>100 \\
30.49 \pm 1.17^{\mathrm{c}} \\
>100\end{array}$ \\
\hline $\begin{array}{l}\text { Ascorbic acid }^{1} \\
\text { Propyl gallate }^{1}\end{array}$ & & $\begin{array}{c}2.00 \pm 0.01^{\mathrm{a}} \\
-\end{array}$ & $\begin{array}{c}- \\
1.00 \pm 0.02 \\
\text { a }\end{array}$ & $\begin{array}{c}- \\
1.00 \pm 0.02^{\mathrm{a}}\end{array}$ \\
\hline
\end{tabular}

Data are expressed as mean \pm SEM $(n=3)$. Different letters along column (DPPH test) or between columns ( $\beta$-carotene bleaching test) indicate statistically significant differences at $P<0.05$ (Bonferroni post-hoc test). ${ }^{1}$ Positive controls.

This fraction and the EtOAc fraction of $S$. officinale showed an interesting antioxidant activity also in the second test, the $\beta$-carotene bleaching method, with $\mathrm{IC}_{50}$ values equal to $12.07 \pm 0.04$. and $12.62 \pm 0.75 \mu \mathrm{g} / \mathrm{mL}$ after $30 \mathrm{~min}$ of incubation, respectively. The best results were obtained for $S$. officinale raw extract, with an $\mathrm{IC}_{50}$ value of $2.61 \pm 0.06 \mu \mathrm{g} / \mathrm{mL}$. This result is particularly interesting if compared with the positive control, propyl gallate.

The capacity of $C$. album and $S$. officinale extracts to protect against lipid peroxidation, induced by tert-butyl hydroperoxide (tert-BOOH), was evaluated in rat-liver microsomes for one hour [20-22]. The antioxidant efficiency of extracts were time-dependent and evaluated as MDA production (in nmol mg ${ }^{-1}$ protein, Figure 3). The obtained results indicated that all extracts are effective antioxidants against tert-BOOH-induced lipid peroxidation, showing a preservation of their efficacy up to one hour.

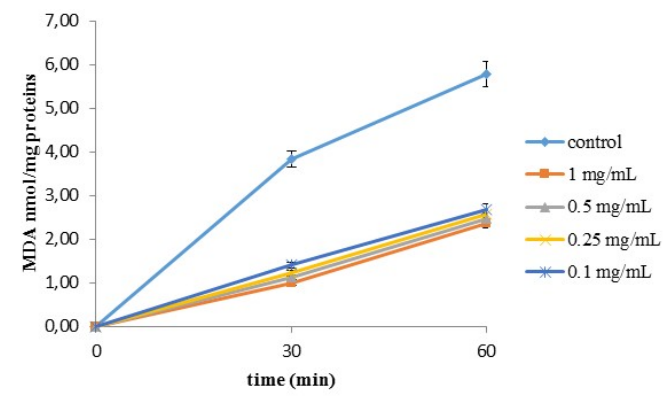

a

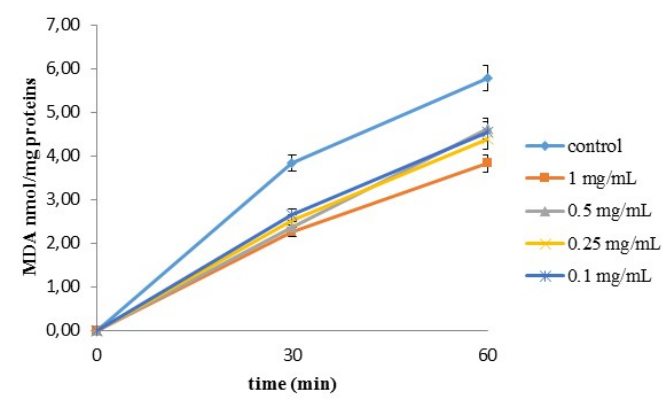

b

Figure 3. Effects of Chenopodium album L. (a) and Sisymbrium officinale (L.) Scop. extract (b) on malondialdehyde (MDA) production induced by tert-butyl hydroperoxide (tert-BOOH) in rat liver microsomal membranes. Results represent the mean \pm SEM of four separate experiments. Overall $P<0.01$.

A good antioxidant potential was already reported for C. album by Pandey [23], who investigated the biological properties of the petroleum ether, methanol, and aqueous extracts by means of (2,2'-azino-bis (3-ethylbenzothiazoline-6-solfonic acid (ABTS) and ferric reducing/antioxidant power (FRAP) methods, and by Chludil and coworkers [24], who studied the influence of soil quality on C. album antioxidant potential. As regards S. officinale, the sample from Calabria here investigated showed a better biological activity compared to literature [25]. 


\subsection{Anti-Inflammatory and Anti-Arthritic Potential}

The anti-inflammatory potential of C. album and S. officinale extracts was first investigated through the assessment of their ability to inhibit the LPS-induced production of NO in the murine macrophage RAW 264.7 cell line. Cells were cultured with different concentrations of investigated samples in the presence of LPS (final concentration $1 \mu \mathrm{g} / \mathrm{mL}$ ). The presence of nitrite, a stable oxidized product of $\mathrm{NO}$, was verified in cell culture medium by means of the Griess reagent $24 \mathrm{~h}$ later.

Then, the potential role of C. album and S. officinale extracts in the treatment of arthritic disorders was assessed in vitro through the evaluation of their capacity to protect bovine serum albumin from heat denaturation. The denaturation of tissue proteins is a major cause of arthritic diseases. Thus, agents able to prevent protein denaturation could be useful for the development of new anti-inflammatory drugs [26].

The observed nitric oxide production inhibition is reported in Figure 4. Cells were treated with different concentrations of raw extracts and fractions, ranging from 25 to $1000 \mu \mathrm{g} / \mathrm{mL}$, with the only exception of the dichloromethane fraction of C. album $(6.25-250 \mu \mathrm{g} / \mathrm{mL})$ and the $n$-hexane fraction of $S$. officinale (12.5-500 $\mu \mathrm{g} / \mathrm{mL})$, as higher concentrations caused cytotoxic effects on the used macrophage cell line. The absence of cytotoxic effects on RAW 264.7 macrophages was verified for all the samples by means of the 3-(4,5-dimethylthiazol-2-yl)-2,5-diphenyltetrazolium bromide (MTT) assay. No toxic effects were detected for the other samples.
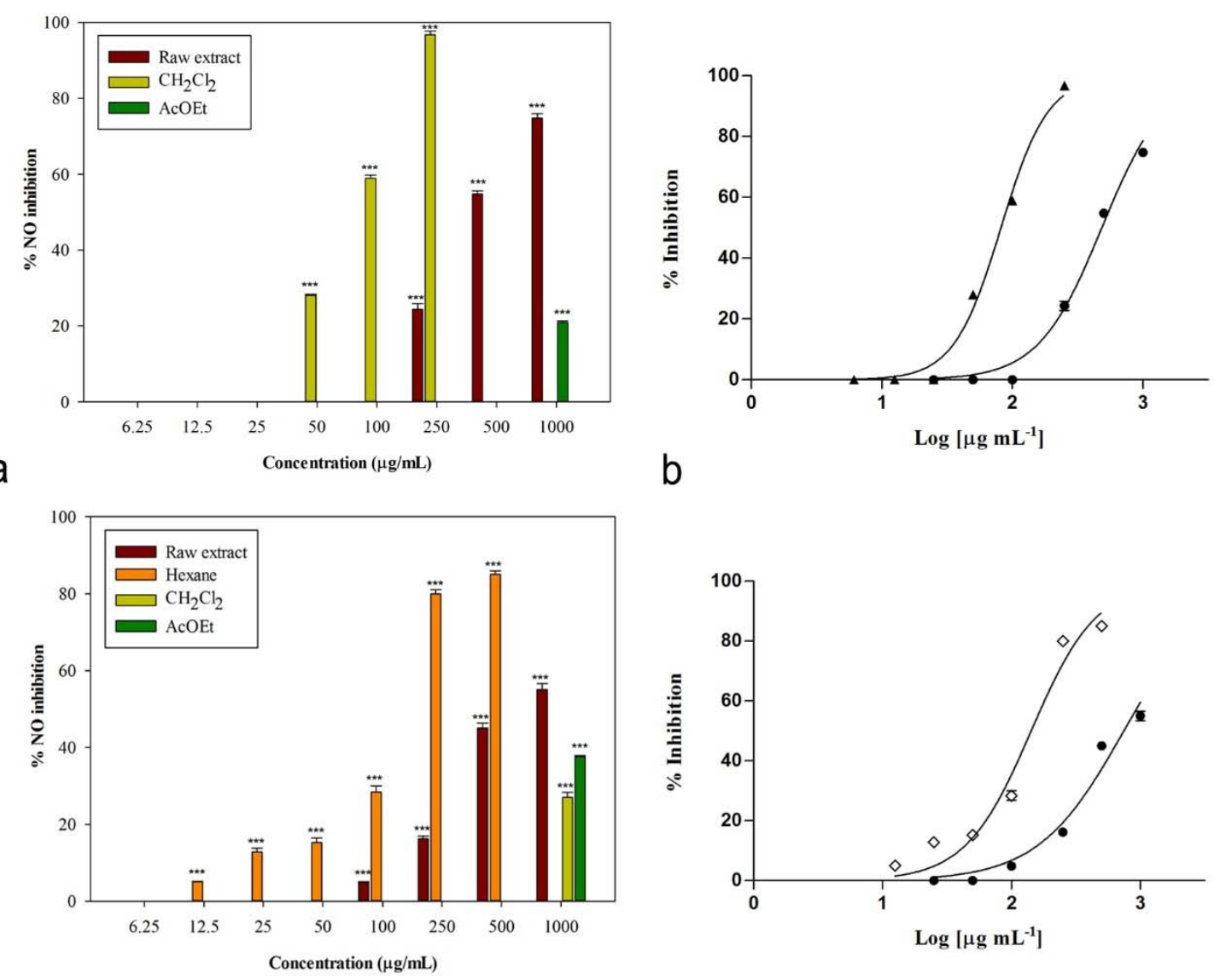

b

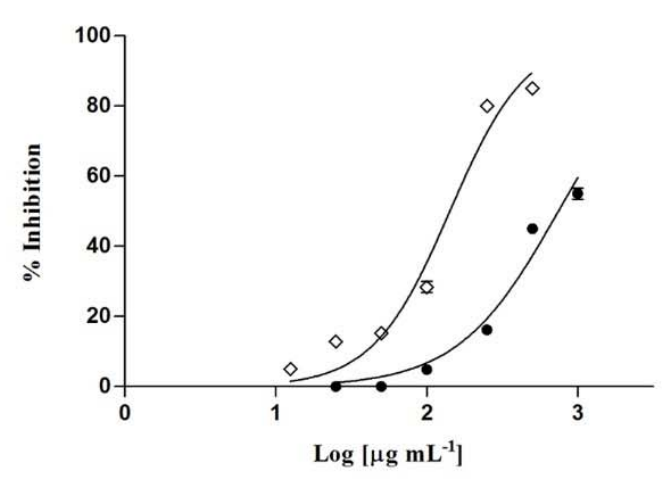

C

d

Figure 4. (a) Nitric oxide production inhibition induced by Chenopodium album L. (b) Non-linear regression analyses: $\bullet$ raw extract, $\Delta \mathrm{CH}_{2} \mathrm{Cl}_{2}$ fraction. (c) Nitric oxide production inhibition induced by Sisymbrium officinale (L.) Scop. and (d) non-linear regression analyses: $\bullet$ raw extract, $\diamond n$-hexane fraction. Data were expressed as means \pm S.E.M. $(n=4)$. ${ }^{* *} P<0.001$ compared to control (Dunnett's test). 
Both raw extracts were effective in inhibiting nitric oxide production, with $\mathrm{IC}_{50}$ values equal to $483.2 \pm 6.4$ and $734.4 \pm 21.2 \mu \mathrm{g} / \mathrm{mL}$ for C. album and S. officinale, respectively (Table 5). A good biological activity was observed for the $n$-hexane fraction of $S$. officinale, with an $\mathrm{IC}_{50}$ value of $142.0 \pm 5.5 \mu \mathrm{g} / \mathrm{mL}$. An excellent inhibitory activity was induced by the dichloromethane fraction of $C$. album, for which an $\mathrm{IC}_{50}$ value equal to $81.7 \pm 0.9 \mu \mathrm{g} / \mathrm{mL}$ was calculated (Table 5). This significant result is interesting if compared to both positive controls $\left(\mathrm{P}<0.05\right.$, Bonferroni post-hoc test), indomethacin $\left(\mathrm{IC}_{50}=58.0 \pm 0.9 \mu \mathrm{g} / \mathrm{mL}\right)$ and L-NAME $\left(\mathrm{IC}_{50}=45.9 \pm 0.5 \mu \mathrm{g} / \mathrm{mL}\right)$. This fraction significantly reduced LPS-induced synthesis of NO in a concentration-dependent manner (Figure 4a), inducing $96.76 \pm 0.94 \%$ inhibition of NO production at the concentration of $250 \mu \mathrm{g} / \mathrm{mL}(\mathrm{P}<0.001$, Dunnett's multiple comparison test). Additionally, at 100 $\mu \mathrm{g} / \mathrm{mL}$ the inhibition percentage was significant compared to control $(P<0.001)$.

Table 5. In vitro inhibitory activity on NO production and anti-arthritic potential.

\begin{tabular}{|c|c|c|c|}
\hline \multirow[t]{2}{*}{ Species } & \multirow[t]{2}{*}{ Sample } & \multicolumn{2}{|c|}{$\mathrm{IC}_{50}(\mu \mathrm{g} / \mathrm{mL})$} \\
\hline & & NO Inhibition & BSA Denaturation Inhibition \\
\hline \multirow[t]{5}{*}{ C. album L. } & Raw extract & $483.2 \pm 6.4^{\mathrm{c}}$ & n.a. \\
\hline & n-Hexane & n.a. & n.a. \\
\hline & $\mathrm{CH}_{2} \mathrm{Cl}_{2}$ & $81.7 \pm 0.9^{a}$ & $975.6 \pm 5.5^{c}$ \\
\hline & EtOAc & n.a. & n.a. \\
\hline & $\mathrm{H}_{2} \mathrm{O}$ & n.a. & n.a. \\
\hline \multirow[t]{5}{*}{ S. officinale (L.) Scop. } & Raw extract & $734.4 \pm 21.2^{\mathrm{d}}$ & n.a. \\
\hline & n-Hexane & $142.0 \pm 5.5^{b}$ & n.a. \\
\hline & $\mathrm{CH}_{2} \mathrm{Cl}_{2}$ & n.a. & $680.9 \pm 13.2^{b}$ \\
\hline & EtOAc & n.a. & n.a. \\
\hline & $\mathrm{H}_{2} \mathrm{O}$ & n.a. & n.a. \\
\hline Indomethacin ${ }^{1}$ & & $58.0 \pm 0.9^{a}$ & - \\
\hline L-NAME $^{1}$ & & $45.9 \pm 0.5^{\mathrm{a}}$ & - \\
\hline Diclofenac $^{1}$ & & - & $15.73 \pm 0.2^{\mathrm{a}}$ \\
\hline
\end{tabular}

Data are expressed as mean \pm SEM ( $n=4$, NO inhibition; $n=3$, Bovine serum albumin (BSA) denaturation). Different letters along columns indicate statistically significant differences at $\mathrm{P}<0.05$ (Bonferroni post-hoc test). n.a. $=$ not active. ${ }^{1}$ Positive controls.

Interestingly, the same fractions showed also a concentration-dependent anti-denaturation effect on heat-treated bovine serum albumin $\left(\mathrm{IC}_{50}=975.6 \pm 5.5 \mu \mathrm{g} / \mathrm{mL}\right.$, Table 5), even if, in this case, the highest activity was observed for the dichloromethane fraction of $S$. officinale extract, with an $\mathrm{IC}_{50}$ value of $680.9 \pm 13.2 \mu \mathrm{g} / \mathrm{mL}$. At the concentration of $1000 \mu \mathrm{g} / \mathrm{mL}$, this fraction was able to induce $63.74 \% \pm 1.77 \%$ inhibition of protein denaturation (Figure 5). At lower concentrations (750 and $500 \mu \mathrm{g} / \mathrm{mL}$ ) inhibition percentages were $51.28 \% \pm 1.09 \%$ and $42.36 \% \pm 0.83 \%$, respectively. The same fraction was still significantly effective at $250 \mu \mathrm{g} / \mathrm{mL}(17.82 \% \pm 1.67 \%, P<0.001$, Dunnett's multiple comparison test).

Usman and coworkers investigated the anti-inflammatory potential of the essential oil of $C$. album leaves from Nigeria, reporting a significant reduction in 12-O-tetradecanoylphorbol-13-acetate (TPA)-induced ear edema in mice [27]. As regards S. officinale, a study conducted by Calcinoni demonstrated that this plant was able to reduce perceived disability in patients claiming vocal tract discomfort [5].

Our work adds interesting information about the anti-inflammatory potential of investigated species, demonstrating their effectiveness in inhibiting the production of the pro-inflammatory mediator nitric oxide. Moreover, to the best of our knowledge, this is the first report concerning the in vitro anti-denaturation effects on bovine serum albumin for these species. 


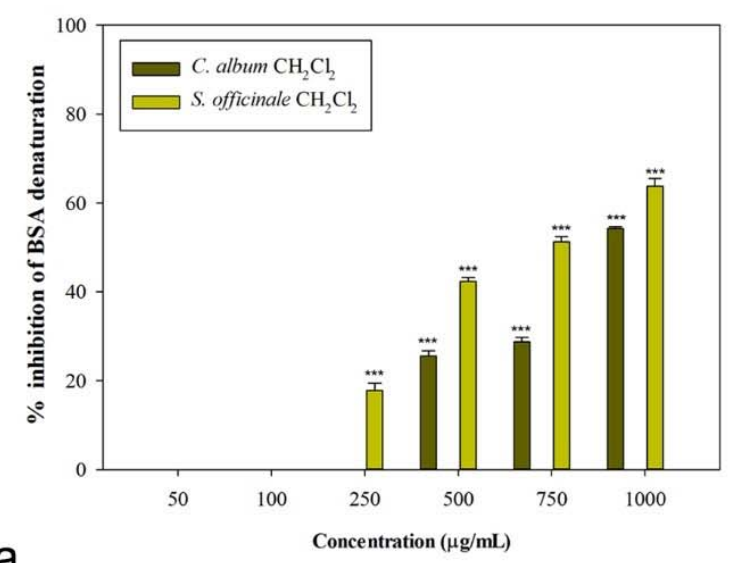

a

Figure 5. (a) Concentration-dependent anti-denaturation effects on heat-treated BSA induced by the dichloromethane fractions of investigated plant extracts. (b) Non-linear regression analyses: $\bullet$ C. album $\mathrm{CH}_{2} \mathrm{Cl}_{2}$ fraction, $\mathbf{S}$. officinale $\mathrm{CH}_{2} \mathrm{Cl}_{2}$ fraction.

\section{Materials and Methods}

\subsection{Chemicals}

Bovine serum albumin, diclofenac sodium, potassium chloride, disodium hydrogen phosphate, sodium chloride, potassium dihydrogen phosphate, DMEM, FBS, PBS, MTT, L-NAME, L-glutamine, penicillin/streptomycin, trypan blue, Griess reagent, indomethacin, Folin-Ciocalteu reagent, aluminum chloride, ascorbic acid, DPPH, $\beta$-carotene, linoleic acid, propyl gallate, Tween 20, EDTA, sucrose, HEPES, trichloroacetic acid (TCA), butylated hydroxytoluene (BHT), hydrochloric acid, tert-butyl hydroperoxide, 2-thiobarbituric acid (TBA), and reference compounds utilized in HPTLC analyses were purchased from Sigma-Aldrich S.p.A. (Italy). The RAW 264.7 cell line was obtained from American Type Culture Collection (ATCC) no. TIB-71, UK. Normal phase glass plates were obtained from Merck (Germany). All the solvents used were reagent grade and were purchased from VWR International s.r.l. (Italy).

\subsection{Extraction Procedure}

The aerial parts from wild plant species were collected in Southern Italy (Calabria) in July 2015 during the flowering stage (leg. F. Conforti, det. F. Conforti). Voucher specimens are deposited in the Herbarium CLU of our University (Table 1). Dried samples were extracted with methanol through maceration at room temperature (plant to solvent ratio $1: 10 \mathrm{~g} / \mathrm{mL}, 48 \mathrm{~h} \times 3$ times). Obtained solutions were then filtered and dried. A fraction of each raw extract (suspended in methanol:water, 9:1) was then extracted with $\mathrm{n}$-hexane. The residue was then suspended in distilled water and extracted successively with dichloromethane and ethyl acetate. Samples were preserved at $-20{ }^{\circ} \mathrm{C}$.

\subsection{Gas Chromatography-Mass Spectrometry (GC-MS) Analyses}

The chemical composition of the $n$-hexane and dichloromethane fractions of the two raw extracts was assessed using a Hewlett-Packard 6890 gas chromatograph with an SE-30 capillary column 100\% dimethylpolysiloxane ( $30 \mathrm{~m}$ length, $0.25 \mathrm{~mm}$ in diameter, $0.25 \mu \mathrm{m}$ film thickness) coupled to a mass spectrometer Hewlett Packard 5973. Helium was used as carrier gas and analyses were run using a programmed temperature from 60 to $280^{\circ} \mathrm{C}$ (rate $16^{\circ} \mathrm{C} / \mathrm{min}$ ) with helium as carrier gas (linear velocity, $0.00167 \mathrm{~cm} / \mathrm{sec}$ ), as previously described [28]. The comparison of spectra with those of the Wiley 138 mass spectral library allowed the identification of compounds. 


\subsection{Total Phenolic Content and Flavonoid Content}

The Folin Ciocalteau reagent was used to determine the total phenolic content of the two raw extracts as previously reported [29]. Briefly, $200 \mu \mathrm{L}$ of each sample $(2 \mathrm{mg} / \mathrm{mL}$ in acetone/ $\mathrm{MeOH} / \mathrm{H}_{2} \mathrm{O} /$ formic acid, 40:40:20:0.1) were added to $1 \mathrm{~mL}$ of Folin-Ciocalteau reagent and $1 \mathrm{~mL}$ of $7.5 \% \mathrm{w} / \mathrm{v}$ sodium carbonate. The absorbance was measured after two hours at $726 \mathrm{~nm}$.

Total flavonoid content was evaluated using a colorimetric method as earlier described [30]. The absorbance of a mixture consisting of sample $(2 \mathrm{mg} / \mathrm{mL}$ in $80 \% \mathrm{EtOH})$ and $2 \% \mathrm{AlCl}_{3}(1 \mathrm{~mL})$ was measured at $430 \mathrm{~nm}$ after 15 min of incubation. Results were calculated from calibration curves based on the standards chlorogenic acid (for phenolics determination) or quercetin (flavonoids analysis), and were expressed as $\mathrm{mg}$ of standard equivalent per $\mathrm{g}$ of dry plant.

\subsection{High-Performance Thin Layer Chromatography (HPTLC) Analyses}

The constituents of the polar fractions from C. album and S. officinale were identified by means of high-performance thin layer chromatography (HPTLC) by means of the CAMAG semi-automated HPTLC system including a Linomat 5 sample applicator connected to a TLC Visualizer and controlled with wincats planar chromatography software.

Samples and reference compounds were dissolved in methanol to a final concentration of 50 and $3 \mathrm{mg} / \mathrm{mL}$, respectively, and spray-applied with a micro-syringe on $20 \times 10 \mathrm{~cm}$ silica gel glass plates (silica $2-10 \mu \mathrm{m} ; 2 \mu \mathrm{m}$ thickness). Operating conditions were the same as previously described [31]. Plates were developed using a mixture of ethyl acetate/dichloromethane/acetic acid/formic acid/water (100:25:10:10:11, v/v/v/v/v). For post-chromatographic derivatization, plates were dipped in freshly prepared NPR reagent and anisaldehyde reagent, and heated at $100{ }^{\circ} \mathrm{C}$ for $5 \mathrm{~min}$. The first reagent was prepared by dissolving diphenylborinic acid aminoethyl ester $(1 \mathrm{~g})$ in AcOEt $(200 \mathrm{~mL})$. The second one by mixing $p$-anisaldehyde $(1.5 \mathrm{~mL})$, sulfuric acid $(2.5 \mathrm{~mL}), \mathrm{AcOH}(1 \mathrm{~mL})$, and ethanol $(37 \mathrm{~mL})$. The plates were examined before and after derivatization under UV light (254 or $366 \mathrm{~nm})$ and white light. Samples were analyzed by co-chromatography with the reference compounds rutin, chlorogenic acid, cinnamic acid, caffeic acid, sinapic acid, p-coumaric acid, naringenin, quercetin, kaempferol, luteolin, ferulic acid, catechin, and naringin.

\subsection{Free Radical Scavenging Activity (FRSA) Assay}

The DPPH method was used to evaluate the radical scavenging activity of extracts and their fractions. The radical 2,2-diphenyl-1-picrylhidrazyl (DPPH, $0.1 \mathrm{mM}$ in $\mathrm{MEOH}, 0.8 \mathrm{~mL}$ ) was mixed with samples $(0.2 \mathrm{~mL}$ ) at concentrations ranging from 5 to $1000 \mu \mathrm{g} / \mathrm{mL}$ (or to ascorbic acid in the positive control group). Absorbance was measured at $517 \mathrm{~nm} 30$ min later [32].

\section{7. $\beta$-Carotene Bleaching Test}

The antioxidant activity was evaluated using the $\beta$-carotene bleaching test. An emulsion was prepared by adding a $\beta$-carotene solution $\left(1 \mathrm{~mL}, 0.5 \mathrm{mg} / \mathrm{mL}\right.$ in $\left.\mathrm{CHCl}_{3}\right)$ to linoleic acid $(0.02 \mathrm{~mL})$ and $100 \%$ Tween $20(0.2 \mathrm{~mL})$, removing chloroform and adding distilled water $(100 \mathrm{~mL})$. Five milliliters of obtained emulsion was mixed with $0.2 \mathrm{~mL}$ of different samples solutions $(0.25-100 \mu \mathrm{g} / \mathrm{mL})$, or to propyl gallate in the positive control group, and incubated at $45^{\circ} \mathrm{C}$. Absorbance was measured at $470 \mathrm{~nm}$ at different times (initial time, $30 \mathrm{~min}$, and $60 \mathrm{~min}$ ). The prevention of $\beta$-carotene bleaching indicated the antioxidant activity of samples [33].

\subsection{Microsomal Suspensions}

The microsomal suspension was prepared from liver of Wistar rats homogenizing the tissue in a PotterElvehjem with a solution, pH 7.5, containing $0.25 \mathrm{M}$ sucrose, $5 \mathrm{mM}$ HEPES, and $0.5 \mathrm{mM}$ EDTA [20,34]. Microsomes were isolated by the nuclear fraction at $8000 \mathrm{~g}$ for $10 \mathrm{~min}$ and subsequently by mitochondrial fraction at 18,000 $\mathrm{g}$ for $10 \mathrm{~min}$. The microsomal fraction was sedimented at 105,000 $\mathrm{g}$ 
for $60 \mathrm{~min}$, washed in $0.15 \mathrm{M} \mathrm{KCl}$, and collected again at 105,000 $\mathrm{g}$ for $30 \mathrm{~min}$ [35]. The microsomes were suspended in $0.1 \mathrm{M}$ potassium phosphate buffer, $\mathrm{pH} 7.5$, and stored at $-80^{\circ} \mathrm{C}$. The protein concentration was determined by the Bio-Rad method [36].

\subsubsection{Addition of Extracts to Microsomes}

Aliquots of extracts were added to the microsomes to give concentrations in the range $0.1-1 \mathrm{mg} / \mathrm{mL}$. Control samples were treated with a water amount equal to those present in extracts-treated microsomes. These were suspended and then were incubated at $37^{\circ} \mathrm{C}$ in the dark in the presence of $\mathrm{t}-\mathrm{BOOH}$.

\subsubsection{Malondialdehyde Formation}

Aliquots of $1 \mathrm{~mL}$ of microsomal suspension were mixed with a solution composed of TCA, TBA, and BHT in $95 \%$ ethanol, and then incubated in a $40{ }^{\circ} \mathrm{C}$ bath for $1 \mathrm{~h}$. Subsequently, the TBA-MDA complex was extracted with $3 \mathrm{~mL}$ of isobutyl alcohol and malondialdehyde (MDA) was measured at $535 \mathrm{~nm}$.

\subsection{Nitric Oxide Production Inhibition}

The ability of plant extracts and their fractions to inhibit NO production was verified in vitro on RAW 264.7 cells stimulated with LPS. Dulbecco's modified Eagle's medium (DMEM) was used as growth medium. It was supplemented with L-glutamine, fetal bovine serum, and a solution of penicillin and streptomycin (1\%, $10 \%$ and $1 \%$, respectively). Cells were cultured at $37^{\circ} \mathrm{C}$ under $5 \%$ $\mathrm{CO}_{2}$. For the experiments, cells were removed from flask by scraping and then seeded onto microplates (96 wells, 100,000 cells/well). After $24 \mathrm{~h}$, medium was removed and fresh DMEM containing samples at different concentrations (6-1000 $\mu \mathrm{g} / \mathrm{mL}$ in DMSO, final ratio of DMSO to medium $0.5 \% \mathrm{v} / \mathrm{v}$ ) and $1 \mu \mathrm{g} / \mathrm{mL}$ LPS was added. After $24 \mathrm{~h}$ of incubation, the Griess reagent was used to evaluate the presence of nitrite, a stable end product of nitric oxide oxidation, in cell culture media. A total of $100 \mu \mathrm{L}$ of Griess reagent was added to $100 \mu \mathrm{L}$ of cell culture supernatant. Absorbance was measured at $550 \mathrm{~nm}$. Indomethacin and the NO synthase inhibitor L-NAME were used as positive controls [37].

The absence of cytotoxic effects on RAW 264.7 macrophages was verified by means of the MTT assay [38]. At the end of the experiments, MTT $(0.5 \%, 100 \mu \mathrm{L} /$ well $)$ was added to the wells. Four hours later, DMSO $(100 \mu \mathrm{L} /$ well $)$ was also added and absorbance was measured at $550 \mathrm{~nm}$.

\subsection{Anti-Arthritic Potential}

The anti-arthritic potential of C. album and S. officinale extracts and fractions was evaluated by means of the in vitro protein denaturation assay reported by Palit and colleagues [39] with some modifications.

To realize the experiment, $2.40 \mathrm{~mL}$ of a $3.5 \%$ bovine serum albumin water solution (BSA) were mixed with $0.10 \mathrm{~mL}$ of samples (concentrations ranging from 1000 to $50 \mu \mathrm{g} / \mathrm{ml}$ in DMSO). Diclofenac sodium $(250 \mu \mathrm{g} / \mathrm{mL})$ was used as positive control. $\mathrm{pH}$ was adjusted at 6.3 using $1 \mathrm{~N} \mathrm{HCl}$ and samples were then incubated at $37^{\circ} \mathrm{C}$ for $20 \mathrm{~min}$ and then heated at $71{ }^{\circ} \mathrm{C}$ for $1 \mathrm{~min}$. After cooling, phosphate buffered saline ( $\mathrm{pH} 6.3,2.5 \mathrm{~mL}$ ) was added to each sample. Buffer was prepared by dissolving $8 \mathrm{~g}$ of $\mathrm{NaCl}, 0.2 \mathrm{~g}$ of $\mathrm{KCl}, 1.44 \mathrm{~g}$ of $\mathrm{Na}_{2} \mathrm{HPO}_{4}$, and $0.24 \mathrm{~g}$ of $\mathrm{KH}_{2} \mathrm{PO}_{4}$ in $800 \mathrm{~mL}$ of distilled water; $\mathrm{pH}$ was adjusted at 6.3 using $1 \mathrm{~N} \mathrm{HCl}$ and the final volume was brought to $1000 \mathrm{~mL}$ with distilled water. Diclofenac sodium $(250 \mu \mathrm{g} / \mathrm{mL})$ was used as positive control.

The turbidity of obtained solutions was measured spectrophotometrically at $660 \mathrm{~nm}$. Product control groups were prepared without bovine serum albumin and the percentage of protein denaturation inhibition was calculated as shown in the following equation:

Inhibition $\%=[1-($ Abs test solution - Abs product control $) /$ Abs untreated control $] \times 100$. 


\subsection{Statistical Analysis}

Experiments were run in triplicate, except for tests involving cell cultures, for which four replicates were performed. Data were expressed as means \pm S.E.M. Normality of data and homogeneity of variances were assessed using D'Agostino-Pearson's K2 test and Levene's test, respectively. Nonlinear regression analyses were performed using Graph-Pad Prism Software (San Diego, CA, USA) in order to deduce the $\mathrm{IC}_{50}$ parameters. One-way ANOVA was carried out to test the statistical differences between treated groups and the control (Dunnett's multiple comparison test) and among treated groups means (Bonferroni post-hoc test, $P \leq 0.05$, SigmaStat Software, SanRafael, CA, USA).

\section{Conclusions}

Botanicals may potentially play an important role in the treatment of anti-inflammatory diseases, with the aim to avoid common undesired side effects of the main synthetic drugs commonly utilized [40, 41]. Herbal remedies and dietary plants used in traditional medicine could be a promising source of new effective drugs [42,43].

In this context, the results of this work proved in vitro the potential effectiveness of C. album and S. officinale, two traditionally used herbal drugs in the treatment of inflammatory disorders. Both species demonstrated to inhibit the production of the pro-inflammatory mediator nitric oxide in LPS-stimulated murine macrophages in a concentration-dependent manner, the dichloromethane fraction of $C$. album being the most active sample $\left(\mathrm{IC}_{50}=81.7 \pm 0.9 \mu \mathrm{g} / \mathrm{mL}\right)$. Moreover, some samples demonstrated an interesting in vitro anti-arthritic effect in experimental studies, showing significant protein anti-denaturation effects, verified on heat-treated bovine serum albumin. Additionally, in this case, C. album dichloromethane fraction was effective, even if to a lesser extent compared to the same fraction of the second species, $S$. officinale, with $\mathrm{IC}_{50}$ values, respectively, equal to $975.6 \pm 5.5$ and $680.9 \pm 13.2 \mu \mathrm{g} / \mathrm{mL}$.

Furthermore, both plant species demonstrated in vitro antioxidant properties, verified by means of the DPPH and $\beta$-carotene bleaching methods. The activity of extracts against lipid peroxidation was also verified in microsomal suspension from rat liver. All extracts were effective antioxidants against tert-BOOH-induced lipid peroxidation, showing a preservation of their activity up to one hour.

In conclusion, the results reported in this study seem to support the traditional use of C. album and S. officinale in the treatment of inflammatory conditions.

Author Contributions: Chemical investigation, V.A., M.M., F.C. and G.S.; biological investigation, M.M., V.P., R.C., S.T. and F.C.; writing-original draft preparation, V.A., M.M. and S.T.; writing-review and editing, F.C. and G.S.

Funding: This research received no external funding.

Conflicts of Interest: The authors declare no conflicts of interest.

\section{References}

1. Nishimura, E.; Suzaki, E.; Irie, M.; Nagashima, H.; Hirose, T. Architecture and growth of an annual plant Chenopodium album in different light climates. Ecol. Res. 2010, 25, 383-393. [CrossRef]

2. Pérez, S.G.; Zavala, M.S.; Arias, L.G.; Ramos, M.L. Anti-inflammatory activity of some essential oils. J. Essent. Oil Res. 2011, 23, 38-44. [CrossRef]

3. Nelly, A.; Annick, D.D.; Frederic, D. Plants used as remedies antirheumatic and antineuralgic in the traditional medicine of Lebanon. J. Ethnopharmacol. 2008, 120, 315-334.

4. Bianco, V.V.; Santamaria, P.; Elia, A. Nutritional value and nitrate content in edible wild species used in southern Italy. III International Symposium Diversification of Vegetable Crops. Acta Hortic. 1996, 467, 71-90.

5. Calcinoni, O. Sisymbrium "Singers' Plant" Efficacy in Reducing Perceived Vocal Tract Disability. J. Otolaryngol. ENT Res. 2017, 8, 00243. [CrossRef]

6. Guarise, M.; Borgonovo, G.; Bassoli, A.; Ferrante, A. Evaluation of two wild populations of Hedge Mustard (Sisymbrium officinale (L.) Scop.) as a potential leafy vegetable. Horticulturae 2019, 5, 13. [CrossRef] 
7. Di Sotto, A.; Vitalone, A.; Nicoletti, M.; Piccin, A.; Mazzanti, G. Pharmacological and phytochemical study on a Sisymbrium officinale Scop. extract. J. Ethnopharmacol. 2010, 127, 731-736. [CrossRef]

8. Dogan, Y.; Baslar, S.; Ay, G.; Mert, H.H. The use of wild edible plants in western and central Anatolia (Turkey). Econ. Bot. 2004, 58, 684-690. [CrossRef]

9. Asfaw, Z.; Tadesse, M. Prospects for sustainable use and development of wild food plants in Ethiopia. Econ. Bot. 2001, 55, 47-62. [CrossRef]

10. Ali-Shtayeh, M.S.; Jamous, R.M.; Al-Shafie', J.H.; Elgharabah, W.A.; Kherfan, F.A.; Qarariah, K.H.; Khdair, I.S.; Soos, I.M.; Musleh, A.A.; Isa, B.A.; et al. Traditional knowledge of wild edible plants used in Palestine (Northern West Bank): A comparative study. J. Ethnobiol. Ethnomed. 2008, 4, 13. [CrossRef]

11. Garnatje, T.; Peñuelas, J.; Vallès, J. Ethnobotany, phylogeny, and 'omics' for human health and food security. Trends Plant Sci. 2017, 22, 187-191. [CrossRef] [PubMed]

12. Vallès, J.; Garnatje, T. A vindication of ethnobotany: Between natural and social science. Mètode Sci. Stud. J. 2016, 6, 22-27. [CrossRef]

13. Arora, S.K.; Itankar, P.R.; Verma, P.R.; Bharne, A.P.; Kokare, D.M. Involvement of NFkB in the antirheumatic potential of Chenopodium album L. aerial parts extracts. J. Ethnopharmacol. 2014, 155, 222-229. [CrossRef] [PubMed]

14. Politi, M.; Braca, A.; Altinier, G.; Sosa, S.; Ndjoko, K.; Wolfender, J.L.; Hostettmann, K.; Jimenez-Barbero, J. Different approaches to study the traditional remedy of 'hierba del canto', Sisymbrium officinale (L.) Scop. Bol. Latinoam. Caribe Plantas Med. Aromát. 2008, 7, 30-37.

15. Marrelli, M.; Cristaldi, B.; Menichini, F.; Conforti, F. Inhibitory effects of wild dietary plants on lipid peroxidation and on the proliferation of human cancer cells. Food Chem. Toxicol. 2015, 86, 16-24. [CrossRef]

16. Marrelli, M.; Conforti, F.; Araniti, F.; Casacchia, T.; Statti, G. Seasonal and environmental variability of non-cultivated edible Cichorioideae (Asteraceae). Plant Biosyst. 2018, 152, 759-766. [CrossRef]

17. Marrelli, M.; La Grotteria, S.; Araniti, F.; Conforti, F. Investigation of the potential health benefits as lipase inhibitor and antioxidant of Leopoldia comosa (L.) Parl.: Variability of chemical composition of wild and cultivated bulbs. Plant Foods Hum. Nutr. 2017, 72, 274-279. [CrossRef]

18. Conforti, F.; Perri, V.; Menichini, F.; Marrelli, M.; Uzunov, D.; Statti, G.A.; Menichini, F. Wild Mediterranean dietary plants as inhibitors of pancreatic lipase. Phytother. Res. 2012, 26, 600-604. [CrossRef]

19. Nicoletti, M.; Petitto, V.; Gallo, F.R.; Multari, G.; Federici, E.; Palazzino, G. The modern analytical determination of botanicals and similar novel natural products by the HPTLC fingerprint approach. In Studies in Natural Products Chemistry; Atta-ur-Rahman, Ed.; Elsevier: Oxford, UK, 2012; pp. 217-258.

20. Trombino, S.; Serini, S.; Di Nicuolo, F.; Celleno, L.; Andò, S.; Picci, N.; Palozza, P. Antioxidant effect of ferulic acid in isolated membranes and intact cells: Synergistic interactions with alpha-tocopherol, beta-carotene, and ascorbic acid. J. Agric. Food Chem. 2004, 52, 2411-2420. [CrossRef]

21. Serini, S.; Cassano, R.; Corsetto, P.A.; Rizzo, A.M.; Calviello, G.; Trombino, S. Omega-3 PUFA loaded in resveratrol-based solid lipid nanoparticles: Physicochemical properties and antineoplastic activities in human colorectal cancer cells in vitro. Int. J. Mol. Sci. 2018, 19, 586. [CrossRef]

22. Trombino, S.; Serini, S.; Cassano, R.; Calviello, G. Xanthan gum-based materials for omega-3 PUFA delivery: Preparation, characterization and antineoplastic activity evaluation. Carb. Polym. 2019, 208, 431-440. [CrossRef] [PubMed]

23. Pandey, S.; Gupta, R.K. Screening of nutritional, phytochemical, antioxidant and antibacterial activity of Chenopodium album (Bathua). J. Pharmacogn. Phytochem. 2014, 3, 1-9.

24. Chludil, H.D.; Corbino, G.B.; Leicach, S.R. Soil quality effects on Chenopodium album flavonoid content and antioxidant potential. J. Agric. Food Chem. 2008, 56, 5050-5056. [CrossRef] [PubMed]

25. Pieroni, A.; Janiak, V.; Dürr, C.M.; Lüdeke, S.; Trachsel, E.; Heinrich, M. In vitro antioxidant activity of non-cultivated vegetables of ethnic Albanians in southern Italy. Phytother. Res. 2002, 16, 467-473. [CrossRef]

26. Chandra, S.; Chatterjee, P.; Dey, P.; Bhattacharya, S. Evaluation of in vitro anti-inflammatory activity of coffee against the denaturation of protein. Asian Pac. J. Trop. Biomed. 2012, 2, S178-S180. [CrossRef]

27. Usman, L.A.; Hamid, A.A.; Muhammad, N.O.; Olawore, N.O.; Edewor, T.I.; Saliu, B.K. Chemical constituents and anti-inflammatory activity of leaf essential oil of Nigerian grown Chenopodium album L. EXCLI J. 2010, 9,181 . 
28. Conforti, F.; Marrelli, M.; Statti, G.; Menichini, F.; Uzunov, D.; Solimene, U.; Menichini, F. Comparative chemical composition and antioxidant activity of Calamintha nepeta (L.) Savi subsp. glandulosa (Req.) Nyman and Calamintha grandiflora (L.) Moench (Labiatae). Nat. Prod. Res. 2012, 26, 91-97.

29. Menichini, G.; Alfano, C.; Provenzano, E.; Marrelli, M.; Statti, G.A.; Somma, F.; Menichini, F.; Conforti, F. Fig latex (Ficus carica L. cultivar Dottato) in combination with UV irradiation decreases the viability of A375 melanoma cells in vitro. Anticancer Agents Med. Chem. 2012, 12, 959-965. [CrossRef]

30. Marrelli, M.; Menichini, F.; Conforti, F. A comparative study of Zingiber officinale Roscoe pulp and peel: Phytochemical composition and evaluation of antitumour activity. Nat. Prod. Res. 2015, 29, 2045-2049. [CrossRef]

31. Menichini, G.; Alfano, C.; Marrelli, M.; Toniolo, C.; Provenzano, E.; Statti, G.A.; Nicoletti, M.; Menichini, F.; Conforti, F. Hypericum perforatum L. subsp. perforatum induces inhibition of free radicals and enhanced phototoxicity in human melanoma cells under ultraviolet light. Cell Prolif. 2013, 46, 193-202.

32. Conforti, F.; Marrelli, M.; Statti, G.; Menichini, F. Antioxidant and cytotoxic activities of methanolic extract and fractions from Senecio gibbosus subsp. gibbosus (GUSS) DC. Nat. Prod. Res. 2006, 20, 805-812. [CrossRef] [PubMed]

33. Conforti, F.; Loizzo, M.R.; Marrelli, M.; Menichini, F.; Statti, G.A.; Uzunov, D.; Menichini, F. Quantitative determination of Amaryllidaceae alkaloids from Galanthus reginae-olgae subsp. vernalis and in vitro activities relevant for neurodegenerative diseases. Pharm. Biol. 2010, 48, 2-9. [PubMed]

34. Tatum, V.L.; Changoit, C.; Chow, C.K. Measurement of malondialdehyde by HPLC with fluorescence detection. Lipids 1990, 25, 226-229. [CrossRef]

35. Ohta, T.; Nakano, T.; Egashira, Y.; Sanada, H. Antioxidant activity of ferulic acid beta-glucuronide in the LDL oxidation system. Biosci. Biotechnol. Biochem. 1997, 61, 1942-1943. [CrossRef]

36. Bradford, M.M. A rapid and sensitive method for the quantitation of microgram quantities of protein utilizing the principle of protein-dye binding. Anal. Biochem. 1976, 72, 248-254. [CrossRef]

37. Conforti, F.; Marrelli, M.; Menichini, F.; Tundis, R.; Statti, G.A.; Solimene, U.; Menichini, F. Chemical composition and protective effect of oregano (Origanum heracleoticum L.) ethanolic extract on oxidative damage and on inhibition of NO in LPS-stimulated RAW 264.7 macrophages. J. Enzyme Inhib. Med. Chem. 2011, 26, 404-411. [CrossRef]

38. Marrelli, M.; Cachet, X.; Conforti, F.; Sirianni, R.; Chimento, A.; Pezzi, V.; Michel, S.; Statti, G.A.; Menichini, F. Synthesis of a new bis (indolyl) methane that inhibits growth and induces apoptosis in human prostate cancer cells. Nat. Prod. Res. 2013, 27, 2039-2045. [CrossRef]

39. Palit, P.; Mukherjee, D.; Mahanta, P.; Shadab, M.; Ali, N.; Roychoudhury, S.; Asad, M.; Mandal, S.C. Attenuation of nociceptive pain and inflammatory disorders by total steroid and terpenoid fraction of Euphorbia tirucalli Linn root in experimental in vitro and in vivo model. Inflammopharmacology 2018, 26, 235-250. [CrossRef]

40. Kumar, S.; Bajwa, B.S.; Kuldeep, S.; Kalia, A.N. Anti-inflammatory activity of herbal plants: A review. Int. J. Adv. Pharm. Biol. Chem. 2013, 2, 272-281.

41. Shah, B.N.; Seth, A.K.; Maheshwari, K.M. A review on medicinal plants as a source of anti-inflammatory agents. Res. J. Med. Plant 2011, 5, 101-115. [CrossRef]

42. Kushagra, N.; Singh, M.K.; Dhansay, D.; Verma, V.K.; Tripathi, D.K. Anti-inflammatory activity and chemo profile of plants used in traditional medicine: A review. J. Chem. Pharm. Res. 2010, 2, 122-130.

43. Rout, S.P.; Choudary, K.A.; Kar, D.M.; Das, L.; Jain, A. Plants in traditional medicinal system-future source of new drugs. Int. J. Pharm. Pharm. Sci. 2009, 1, 1-23.

(C) 2019 by the authors. Licensee MDPI, Basel, Switzerland. This article is an open access article distributed under the terms and conditions of the Creative Commons Attribution (CC BY) license (http://creativecommons.org/licenses/by/4.0/). 